Portland State University

PDXScholar

Environmental Science and Management

Faculty Publications and Presentations

$4-22-2011$

\title{
The Aquarium Trade as an Invasion Pathway in the Pacific Northwest
}

\author{
Angela L. Strecker \\ Portland State University, angela.strecker@wwu.edu \\ Philip M. Campbell \\ University of Washington - Seattle Campus \\ Julian D. Olden \\ University of Washington - Seattle Campus
}

Follow this and additional works at: https://pdxscholar.library.pdx.edu/esm_fac

Part of the Aquaculture and Fisheries Commons, Environmental Monitoring Commons, and the Terrestrial and Aquatic Ecology Commons

Let us know how access to this document benefits you.

\section{Citation Details}

Strecker, A. L., Campbell, P. M., \& Olden, J. D. (2011). The aquarium trade as an invasion pathway in the Pacific Northwest. Fisheries, 36(2), 74-85.

This Post-Print is brought to you for free and open access. It has been accepted for inclusion in Environmental Science and Management Faculty Publications and Presentations by an authorized administrator of PDXScholar. Please contact us if we can make this document more accessible: pdxscholar@pdx.edu. 
11 Angela L. Strecker

12 Philip M. Campbell

13 Julian D. Olden*

14

15 School of Aquatic and Fishery Sciences, University of Washington, Seattle, WA, USA 98105

$23 *$ Corresponding author: J.D. Olden (tel. 206-616-3112, email. olden@uw.edu)

24 Running head: Aquarium trade and aquatic invasions

25 


\section{Abstract}

27 The aquarium trade moves thousands of species around the globe, and unwanted organisms may

28 be released into freshwaters, with adverse ecological and economic effects. We report on the first

29 investigation of the ornamental pet trade as an invasion pathway in the Pacific Northwest region

30 of the United States, where a moderate climate and a large human population present ample

31 opportunities for the introduction and establishment of aquarium trade species. Results from a

32 regional survey of pet stores found that the number of fish $(n=400)$ and plant $(n=124)$ species

33 currently in the aquarium trade is vast. Pet stores import thousands of fish every month, the

34 majority of which (58\%) are considered to pose an ecological threat to native ecosystems. Our

35 propagule pressure model suggests that approximately 2,500 fish (maximum $\sim 21,000$

36 individuals) are likely released annually to the Puget Sound region by aquarists, and that water

37 temperatures in many parts of Washington are suitable for establishment of populations. In

38 conclusion, the aquarium trade may be a significant source of past and future invasions in the

39 Pacific Northwest, and we recommend enhanced public education programs, greater regulation

40 of the aquarium industry, and improved legislation of nonnative species in the ornamental trade. 


\section{INTRODUCTION}

43 Human activities have greatly increased the number and geographical extent of aquatic invasive

44 species (AIS) throughout the United States and globally. Prevention of species introductions is

45 considered the cornerstone of invasive species management (Vander Zanden and Olden 2008),

46 yet integrated approaches to managing invasion vectors (sensu Ruiz and Carlton 2003) are

47 difficult to develop and implement because pathways to aquatic species introductions are

48 diverse, dynamic over time, and vary both taxonomically and geographically (e.g., Moyle and

49 Marchetti 2006, Ricciardi 2006). An understanding of the full complement of invasion pathways

50 is critical to improve policy actions, guide integrated management strategies, and enhance

51 educational campaigns aimed at reducing the threat of future invasions (Lodge et al. 2006).

52 To date, considerable research activity and management attention has focused on

53 unintentional pathways to AIS introductions through ballast-water transfer in ships (e.g., Carlton

54 and Geller 1993, Ruiz et al. 1997), transport via trailered boats (e.g., Leung et al. 2006,

55 Rothlisberger et al. 2010), bait-bucket releases by recreational anglers (e.g., Litvak and Mandrak

56 1993, DiStefano et al. 2009), and escapes associated with aquaculture (e.g., Naylor et al. 2001,

57 De Silva et al. 2009). By contrast, the ornamental pet and aquarium trade has only recently been

58 recognized as a major pathway for freshwater fish and plant introductions (Copp et al. 2010).

59 This is despite the fact that the ornamental pet trade represents a multi-billion dollar industry that

60 includes thousands of foreign species and has grown by 14\% annually since the 1970s (Padilla

61 and Williams 2004, Cohen et al. 2007). Although the import of some nonnative species common

62 to the pet trade are regulated by certain countries (e.g., reptiles in Australia and New Zealand),

63 ornamental fish generally have not received attention from regulatory agencies (Thomas et al.

64 2009, Secretariat of the Convention on Biological Diversity 2010). Additionally, reliable record 
65 keeping of the type and number of organisms currently in the trade is lacking (Schlaepfer et al.

66 2005, Smith et al. 2008, Chang et al. 2009). Given the present uncertainty in the taxonomy of

67 many ornamental fish and plant species within the aquarium trade, as well as the widespread

68 contamination of many aquarium plants with unidentified organisms (e.g., molluscs: Keller and

69 Lodge 2007), our ability to assess invasion risk associated with this pathway is limited.

70 Aquarium trade species are introduced when owners release unwanted organisms into

71 natural waterbodies for various reasons, including large size, humane treatment, aggressiveness,

72 and high reproductive rates (Padilla and Williams 2004, Gertzen et al. 2008). The most popular

73 fish sold in the aquarium trade are also the most likely to be introduced and establish in

74 freshwater habitats (Duggan et al. 2006). Although the aquarium trade and its associated vectors

75 have been increasingly recognized as a primary pathway of biological invasions in the

76 Laurentian Great Lakes region (Rixon et al. 2005, Cohen et al. 2007, Gertzen et al. 2008) and the

77 San Francisco Bay-Delta region (Chang et al. 2009), surprisingly little is known regarding the

78 scope of the issue in the Pacific Northwest of the United States. In a region where invasive

79 species are considered a significant threat to native biodiversity, ecosystem function, and

80 culturally- and economically-important Pacific salmon (Sanderson et al. 2009), it is imperative

81 that scientific research is available to quantify the strength of the aquarium trade as a pathway of

82 new invasions. In Washington and Oregon, there are a number of plant and animal species that

83 have likely been introduced into the wild via the aquarium trade, including oriental weatherfish

84 (Misgurnus anguillicaudatus), Amur goby (Rhinogobius brunneus), red-bellied pacu (Piaractus

85 brachypomus), goldfish (Carassius auratus), red swamp crayfish (Procambarus clarkii), Chinese

86 mystery snail (Cipangopaludina chinensis malleata), Eurasian watermilfoil (Myriophyllum 
87 spicatum), and parrot feather (Myriophyllum aquaticum $)^{1}$. Thus, the scope of this problem is

88 significant. Furthermore, many aquarium species may become more successful at establishing in

89 higher latitudes with warmer temperatures projected to occur under climate change scenarios

90 (Rahel and Olden 2008, Chang et al. 2009).

91 Our paper is the first to examine the ornamental pet trade as an invasion pathway in the

92 Pacific Northwest region of the United States, where a moderate climate-in combination with a

93 large and growing human population-presents ample opportunities for the introduction and

94 establishment of aquarium trade species. We combine data, gathered over time, from a regional

95 survey of aquarium pet stores with a detailed investigation of fish and plant sales to quantify the

96 type and number of organisms in the ornamental trade. From this we examined selected common

97 aquarium fish species with high invasion potential according to previous invasion history and

98 thermal suitability for establishment in Washington State waters. Next, we report on the results

99 from a survey of live organism used by aquarists, which is used to parameterize a model of 100 propagule pressure to estimate the number of aquarium fish likely to be introduced annually to

101 the Puget Sound region of western Washington.

102

103 MethodS

104 Store Inventory Surveys and Aquarist Questionnaires

105 We conducted an intensive (temporal trends in a single store) and extensive (spatial trends from

106 multiple stores) survey of pet stores in the Puget Sound area of Washington to document the

107 numbers and types of fish and plant taxa in the ornamental pet trade (Figure 1). The intensive

108 survey analyzed monthly sale invoices from a single (large and independent) pet store in 2007.

109 All fish and plant species were identified and individuals counted. Fish were separated into

\footnotetext{
${ }^{1}$ http://nas.er.usgs.gov/
} 
110 ornamental (i.e., fish of primary interest for viewing) and feeder (i.e., to feed to other fish)

111 species. When there was a disparity between a store label scientific name and common name, we

112 used the scientific name provided in FishBase (Froese and Pauly 2009). Additionally, 30 pet

113 stores in Snohomish, King, and Pierce counties were surveyed over a two-week period in

114 February 2008 to regionally characterize the ornamental pet trade (Figure 1). Two different

115 national pet store chains were chosen for the survey (chain $A, n=14$; chain $B, n=8$ ), as well as

116 eight independently owned stores. There is some evidence that independent retailers differ in the

117 numbers and types of species sold compared to chain stores (Chang et al. 2009); understanding

118 differences between store types can help direct educational efforts. Preliminary analyses

119 indicated that the two sets of chain stores differed in the numbers and types of species sold,

120 therefore, we analyzed the chains separately. Stores were visited a day after receiving their fish

121 and plant shipment (determined by contacting the store managers) to enumerate organisms

122 before they were purchased, but after any had died from travel stress. This ensured that our

123 survey accurately reflected the current inventory of store. Time constraints precluded the

124 enumeration of individual plants, resulting in species being reported as present or absent.

125 Fish and plant taxa observed in our regional survey were compared to the USGS

126 Nonindigenous Aquatic Species $\operatorname{list}^{1}$ and the Washington State Aquatic Nuisance Species list ${ }^{2}$ to

127 determine whether the species have a demonstrated history of invasion in other regions of the

128 United States. The USGS defines nonindigenous species as species that are outside of their

129 historic or native range, whereas Washington State defines invasive species as species that are

130 not historically native to the state. Previous invasion history is one of the best predictors of

131 invasion potential (Ricciardi and Rasmussen 1998). For the purposes of our study these taxa

132 were designated as "invasive." Next, optimal and lethal temperature requirements for selected

\footnotetext{
${ }^{2}$ http://wdfw.wa.gov/ais/; http://www.ecy.wa.gov/programs/wq/plants/weeds/exotic.html
} 
133 fish species were obtained from FishBase (Froese and Pauly 2009): when lethal limits were

134 unavailable, values were obtained from primary literature (white cloud mountain minnow,

135 Tanichthys albonubes: Cheverie and Lynn (1963); goldfish, Carassius auratus: Ford and

136 Beitinger (2005); molly, Poecilia sphenops: Hernández and Bückle (2002); koi carp, Cyprinus

137 carpio carpio: Opuszyňski et al. (1989)). These species were chosen because they represent a

138 cross-section of species common to aquarium and pet stores; they have been identified

139 previously as species with potential to establish in temperate North America and Washington

140 State (Tabor et al. 2001, Rixon et al. 2005, Gertzen et al. 2008); and there was optimal and lethal

141 temperature range data available in the literature. Optimum temperature was defined as the range

142 of temperatures in which fish species typically habituate in the wild, whereas lethal temperatures

143 indicate absolute minimum and maximum temperatures that fish can survive in under

144 experimental settings (Brett 1956). Additionally, data layers for stream water temperatures from

145 2000-2008 were obtained from 236 monthly monitoring sites in the Environmental Protection

146 Agency's STORET Database ${ }^{3}$. Water temperature data were summarized as mean annual

147 temperature because values from winter months (i.e., minimum values) were not consistently

148 available. We use stream temperatures as our proxy of water temperatures across the state

149 because data from a suitable number of lakes was not available.

150 A survey of 92 aquarists was conducted at an independent pet store (same store as the

151 intensive survey) in June 2008 to assess the numbers of pet fish owned, and to estimate the

152 proportion of aquarists releasing fish or plants into local waterways. Questions asked included:

153 1) total number of freshwater fish species typically owned each year; 2) whether or not the owner

154 had released live fish or plants into the wild in their lifetime; 3) where live fish and/or plants

\footnotetext{
${ }^{3}$ http://www.epa.gov/storet/dbtop.html
} 
155 were released; and 4) methods of deposing of fish and plants. Questionnaires were randomly

156 given to aquarists in the store, and responses were anonymous.

158 Analysis of Taxa Currently in the Pet Aquarium Trade

159 The number of fish and plant species per store, and the number of fish individuals per store

160 recorded during the spatial survey of pet stores were averaged within store category (chain A,

161 chain B, and independent). Fish abundance and number of fish species were ln-transformed, and

162 the number of plant species was square-root transformed prior to analysis to normalize data. We

163 used analysis of variance (ANOVA) tests, followed by a Tukey HSD post hoc test, to examine

164 differences among store types in fish abundance, and fish and plant species richness.

165 Additionally, we performed a multivariate analysis to examine similarities and differences in the

166 abundances of each fish species sold across the different store types. Fish species that occurred in

$167<10 \%$ of stores were excluded from the analysis, and counts were standardized to $z$-scores to

168 reduce the influence of rare and/or abundant taxa. We used non-metric multidimensional scaling

169 (NMDS) to summarize store differences, as NMDS is effective with non-normal data and can

170 use any distance measure (Legendre and Legendre 1998). We used the Bray-Curtis dissimilarity

171 index, and tested for significance of the ordination with randomization tests. According to

172 multivariate stress values we found that the optimal ordination utilized three dimensions.

173 Ordination analyses were performed using the MASS library in R (R Development Core Team

174 2010).

175

176 Propagule Pressure Model 
177 One of our objectives was to estimate the number of fish likely to be introduced annually to the

178 Puget Sound region of Washington (King, Snohomish, and Pierce counties), which was the

179 location of our regional survey, and held the most populated counties in the state. We used the

180 results of our aquarist survey to parameterize a propagule pressure model by modifying the

181 approach of Gertzen et al. (2008). The model structure is:

182

propagule pressure $=M \cdot P(I) \cdot N \cdot P(R \mid I)$

183 where $M$ is the number of households that own aquarium fish, $P(I)$ is the probability that an

184 owner is a releaser, $N$ is average number of fish owned annually, and $P(R \mid I)$ is the probability

185 fish are released given that an owner is a releaser (Gertzen et al. 2008). We based the parameters

$186 P(I)$ and $N$ on data from our aquarist survey, whereas $P(R \mid I)$ was derived from Gertzen et al.

187 (2008). We used a Bayesian approach to incorporate uncertainty about the representativeness of

188 our values in the model. Bayesian statistics consider prior information in the determination of

189 parameters from a data set. Thus, we created probability distributions that reflected our data: we

190 multiplied these distributions by each other to generate a joint probability distribution.

191 The number of households that own aquarium fish, $M$, was determined by multiplying the

192 number of households in King, Snohomish, and Pierce counties (1,196,568; US Census 2000 $\left.{ }^{4}\right)$

193 by the percentage of U.S. households that own fish (10.6\%), and by the percentage of fish in the

194 aquarium trade that are freshwater (96\%) (values from Chapman et al. 1997). $P(I)$, the

195 probability of being a releaser, was a binary variable determined from survey data and modeled

196 with a binomial distribution (i.e., heads or tails), which reflects the uncertainty from our random

197 survey of 92 people (Bolker 2008). $N$, the number of fish owned annually, was determined from

198 our survey and was modeled with a negative binomial distribution. In a negative binomial

199 distribution, the variance is larger than the mean (Bolker 2008), which reflects the large number

${ }^{4} \mathrm{http}: / / \mathrm{www} . c e n s u s . g o v / \mathrm{main} / \mathrm{www} / \mathrm{cen} 2000 . \mathrm{html}$ 
200 of aquarists who own a small number of fish (e.g., $\leq 5)$, but that a small number of aquarists own

201 large numbers of fish. $P(R \mid I)$, the probability that fish are released given that the owner is a

202 releaser, was based on the value of Gertzen et al. (2008) (5.1\%) and modeled with a beta

203 distribution that is bound by 0 and 1 (Bolker 2008). Each probability distribution $(P(I), N$, and

$204 P(R \mid I))$ was then combined with a uniform flat prior to generate posterior distributions; we used

205 uniform priors as we had no prior expectations about model parameters (Bolker 2008, Gertzen et

206 al. 2008). Finally, all combinations of the posterior distributions and the constant, $M$, were

207 multiplied together to create a joint probability distribution that reflects the inherent uncertainty

208 in our survey data. All propagule pressure model steps were performed in R (R Development

209 Core Team 2010).

210

211 RESUlTS

212 A year-long intensive survey of a pet store in the Puget Sound area revealed a distinct peak in the

213 number of ornamental fish, the number of total fish (ornamentals + feeder fish), and number of

214 plants purchased starting in late spring (February and March) and extending through the summer

215 to September (Figure 2). Fish sales peaked in May, with $>9,700$ fish purchased in the store, half

216 of which were ornamental fish, whereas sales for plants peaked in July, at >700 plants (Figure 2).

217 Our regional survey of 30 pet stores identified 400 fish species and 124 plant taxa

218 currently in the ornamental trade, a number that represents the minimal species pool for the

219 Pacific Northwest region. None of the fish species are native to Washington State and only 8

220 plant species are natives. Of the 400 fish species, 29 occurred in greater than $75 \%$ of stores,

221 including two taxa, tiger barb (Puntius tetrazona) and three spot gourami (Trichogaster

222 trichopterus), which occurred in all of the stores surveyed (Table 1). Other commonly 
223 encountered fish species included goldfish, Siamese fighting fish (Betta splendens), several

224 different tetras, mollies, and guppies (Poecilia spp.) (Table 1). Additionally, a number of species

225 that have previously been detected in the wild in Washington State were found in a lower

226 proportion of stores in the survey: koi carp $=60 \%$, oriental weatherfish $=33 \%$, and Amazon

227 sailfin pleco (Pterygoplichthys pardalis) $=3 \%$. Plant species occurred with lower frequency: the

228 top species, Amazon sword (Echinodorus amazonicus), occurred in $77 \%$ of stores, and an

229 additional 19 taxa occurred in $>25 \%$ of stores (Table 2 ). On average, $58 \%$ of fish individuals,

$23043 \%$ of fish species, and $5 \%$ of plant species found in pet stores were considered invasive

231 according to the USGS Nonindigenous Aquatic Species list and the Washington State Aquatic

232 Nuisance Species list. However, the maximum number of invasive taxa encountered in a single

233 store in our survey indicated that invaders comprised up to $72 \%$ of fish individuals, $61 \%$ of fish

234 species, and $17 \%$ plant species in a store. Further, a number of fish and plant species in our

235 survey are within the same genera as species that are considered invasive (Table 1 and 2).

236 Additionally, in one store we found an aquatic plant species, the water chestnut (Trapa natans),

237 which is banned for sale by the Washington State Department of Agriculture.

238 As many aquarium species are tropical in origin, their minimum optimal temperatures

239 typically exceed winter water temperatures observed in temperate waterbodies (Table 1, Figure

240 3). However, several aquarium species that are prevalent in the ornamental trade have lower-

241 lethal and minimum optimal temperatures that are found well within the range of mean annual

242 stream water temperatures in Washington State (Figure 3). This includes several taxa, such as the

243 white cloud mountain minnow and the oriental weatherfish, which may have high invasion

244 potential. Oriental weatherfish have established a population in Washington (Tabor et al. 2001),

245 and the white cloud mountain minnow are considered a high risk invader in the United States as 
a result of broad thermal tolerance (Rixon et al. 2005). Additionally, koi carp and goldfish (both

247 present in Washington) have very broad thermal tolerance ranges, suggesting that these species

248 may have elevated establishment potential. Our estimates of concordance between fish species

249 thermal tolerance and water temperatures in Washington State may be conservative, as lakes may

250 exhibit greater thermal heterogeneity compared to streams.

251 We found differences between fish and plant inventories from our regional survey of 252 chain stores and a set of independent stores. Chain A had significantly lower numbers of fish 253 individuals per store compared to chain B (ANOVA: $F_{2,27}=9.56, p<0.01$; Tukey HSD $p<$ 254 0.05), but neither chain store was different from the set of independent stores (Tukey HSD $p>$ 255 0.05) (Figure 4A). Chain A also had significantly fewer fish species compared to both chain B 256 and independent stores (ANOVA: $F_{2,27}=13.00, p<0.01$; Tukey HSD $p<0.05$ ), but there was 257 no difference between chain B and independents (Tukey HSD $p>0.05$ ) (Figure 4B). We found 258 no differences in the number of plant species between store types (ANOVA: $F_{2,27}=0.75, p=$ 259 0.48) (Figure 4C). Results from the multivariate analysis on fish abundance revealed strong 260 clustering of store types in ordination space (Figure 5). Little overlap of stores in multivariate 261 space was observed, suggesting that store types have fairly distinctive inventories of ornamental

262 fish (although clear similarities exist in that all stores have a core suite of species in their 263 inventories). Most notably, stores that are independently owned occupied the greatest area in 264 ordination space, suggesting that they carry the highest diversity of fish species (Figure 5, 265 supported by Figure 4).

266 The results from our questionnaire indicated that, on average, aquarists owned $\sim 9$ fish

267 (median $=5$ ) and that $6.4 \%$ of aquarists had released live fish in the past. The majority of 268 introductions were into lakes or streams. Using a Bayesian statistical approach, we estimated that 
269 the most likely number of fish introduced annually into the Puget Sound area was 2,536;

270 however, the $95 \%$ confidence interval suggests that 20,869 fish could be introduced in a year

271 (Figure 6).

273 DISCUSSION

274 Using a combination of regional store surveys, aquarist questionnaires, and statistical models, we 275 have demonstrated that the number of fish $(n=400)$ and plant $(n=124)$ species currently in the 276 aquarium trade is vast, the majority of species in the trade are not native to the region, and that 277 this introduction pathway deserves greater research and regulation in the Pacific Northwest. Pet 278 and aquarium stores import thousands of fish every month, the majority of which (58\%) are 279 considered to pose an ecological threat to native ecosystems. Our model suggests that up to 28021,000 fish (average of 2,500 individuals) are likely released into the wild each year in the Puget

281 Sound area by aquarists, and that water temperatures in many parts of Washington State are 282 suitable to allow establishment of populations. The predictions of our model suggest that the pet 283 trade is a significant pathway of AIS introductions, particularly around populated urban centers, 284 yet far greater research effort and funding for prevention have been directed towards boater 285 movement as an invasion pathway (e.g., Leung et al. 2006, Rothlisberger et al. 2010). This is 286 particular true in Washington State where management efforts continue to focus on preventing 287 invasions via trailered boats (State of Washington Joint Legislative Audit \& Review Committee 288 2010). To illustrate the potential importance of the ornamental pet trade, we compared several 289 different features of the aquarium and boater pathways (Table 3). Our comparison suggests that 290 the number of aquarists is similar to the number of registered boats in Washington State (i.e., 291 vector strength), and that propagule pressure from the aquarium trade is high relative to boats for 
292 some taxonomic groups (e.g., fish, invertebrates: Duggan (2010)), but low for others (e.g.,

293 plants). Management and educational challenges are likely very different between the pathways;

294 the distribution of aquarists (i.e., reflecting the location of potential introductions) is spatially-

295 diffuse, whereas the distribution of boat launches is well defined. This comparison underscores

296 the importance of this understudied pathway, and highlights the significant management and

297 educational challenges that the aquarium pathway represents.

298 The regional survey of 30 pet and aquarium stores indicated that independently owned

299 stores tend to carry a greater number of — and a more unique variety of - fish species compared

300 to some chain stores (e.g., chain A: Figures 4,5). Despite the lower diversity, chain store B had a

301 larger inventory available for sale; presumably, related to faster turnover of stocks. Our results

302 concur with the study of Chang et al. (2009) in the San Francisco Bay-Delta region, where

303 independent retailers generally sold greater numbers of fish species compared to chain stores.

304 Goldfish, Siamese fighting fish, neon tetras (Paracheirodon innesi), and guppies and/or mollies

305 all occur frequently in our study, as well as those of Gertzen et al. (2008) and Rixon et al. (2005)

306 conducted in the Laurentian Great Lakes region. In our survey, the number of aquatic plants was

307 similar between store types, but the composition tended to be relatively different, as only six

308 species occurred in more than half of the stores surveyed. In contrast to aquarium fish, the most

309 common aquatic plants differed from a similar study conducted in another region: only two taxa,

310 Amazon sword and hornwort (Ceratophyllum demersum), were frequently encountered in our

311 study and the study conducted by Rixon et al. (2005). Overall, the moderate climate of the

312 Pacific Northwest, as well as large population centers in the Puget Sound basin, suggests that

313 freshwater ecosystems are threatened by the establishment of nonnative species from the

314 aquarium trade. We expect that other large urban centers in the Pacific Northwest, such as 
315 Portland, Oregon and Vancouver, British Columbia, would be similarly at risk of nonnative

316 species introductions via the aquarium trade pathway, and thus, should be targets for educational

317 campaigns. Further, climate change will certainly increase establishment of nonnative aquarium

318 and pet trade species in the Pacific Northwest, where temperatures are predicted to increase by $>$

$3193^{\circ} \mathrm{C}$ by the end of the $21^{\text {st }}$ century (Mote and Salathé Jr. 2010). Additionally, nonnative species

320 introductions via the aquarium trade in milder tropical and sub-tropical habitats will have

321 substantially greater establishment success because of greater thermal suitability. Indeed,

322 established populations of aquarium trade species have been increasingly detected in the

323 southern United States (e.g., Florida: Padilla and Williams 2004).

$324 \quad$ Our study identified several fish species that may be of particular concern for

325 establishment of populations via the aquarium pathway. The oriental weatherfish currently has

326 an established, but limited, distribution in Washington State (i.e., Lake Washington basin in

327 Seattle: Tabor et al. 2001), and further invasions seem likely without successful intervention and

328 management of this pathway. According to our regional survey of pet stores, oriental weatherfish

329 are found in chain and independent stores, but are currently more common in the inventories of

330 chain stores compared to independent stores (Figure 5). The invasion of oriental weatherfish may

331 have serious consequences for fisheries in the Pacific Northwest. Perhaps most notably, the virus

332 birnavirus LV1 was isolated from invasive oriental weatherfish in Australia (Lintermans et al.

333 1990). Birnavirus LV1 is related to the infectious pancreatic necrosis virus, a disease of salmonid

334 fish (Wolf 1988). Additionally invasive parasites have been found in oriental weatherfish (Dove

335 and Ernst 1998). Further, it has been shown that oriental weatherfish can reduce the abundance

336 and biomass of macroinvertebrates (Keller and Lake 2007) and prey on fish larvae (Logan et al. 
337 1996). Altogether, these factors suggest that oriental weatherfish may have significant effects on

338 native fish populations and should be a target for invasion vector management.

339 A number of additional fish and plant species are currently in the ornamental pet trade

340 and are regulated or prohibited in Washington State. Strikingly, we found the water chestnut

341 (Trapa natans) for sale in one store; a species which is banned for sale by the Washington

342 Department of Agriculture. Although we did not report on invertebrates, we also found a single

343 crayfish species of the Family Cambaridae in a pet store: taxa from this family are prohibited by

344 the Washington Department of Fish and Wildlife. Additionally, goldfish and koi carp are

345 considered regulated fish (e.g., species may not be released into state waters) by the Washington

346 Department of Fish and Wildlife: goldfish were found in almost all surveyed pet stores (97\%),

347 and koi carp were found in $60 \%$ of the stores. The federal USGS Nonindigenous Aquatic Species

348 list has designated oriental weatherfish and Amazon sailfin pleco as invasive species in

349 Washington State: both species were found with a much lower frequency in pet store inventories

350 compared to goldfish and koi carp (oriental weatherfish: 33\%; Amazon sailfin pleco: $3 \%$ ). We

351 recommend that research and management efforts target species that have been identified by the

352 state and federal governments as threats to native organisms.

\section{Recommendations}

355 Our study represents the first scientific investigation of the ornamental pet trade in the Pacific

356 Northwest, thereby enhancing the scientific basis for improving policy and management intended

357 to reduce the threat of this pathway. Based on our findings we have three primary

358 recommendations to slow the introduction of AIS from the pet trade. 
First, we believe that public education programs targeted at the interface of aquarium

360 owners and retailers will likely have the greatest success. One such program, Habitattitude ${ }^{\mathrm{TM}}$, is

361 a partnership of the Pet Industry Joint Advisory Council, the U.S. Fish and Wildlife Service, and

362 NOAA National Sea Grant College Program, with the mandate, “...to eliminate the transfer and

363 survival of any species outside of [an] enclosed, artificial system, which has the potential to

364 cause the loss or decline of native plants and animals." The Habitattitude ${ }^{\mathrm{TM}}$ program supplies

365 educational materials (e.g., pamphlets and stickers) to pet stores, as well as plastic bags with the

366 message "Do not release fish and aquatic plants." This is an important step towards educating

367 aquarium owners about the harm of releasing live organisms into the wild; however, our study

368 found that these materials were only present in chain stores and absent from independent

369 retailers. We have demonstrated that independent stores tend to carry a larger variety of fish

370 species compared to chain stores, therefore, we recommend that independent retailers should be

371 the next focal point of the Habitattitude ${ }^{\mathrm{TM}}$ campaign and other private and government funded

372 education programs (Table 4). Efforts to educate aquarists on the repercussions of releasing

373 aquarium fish and plants to the wild will only be successful if the distribution of educational

374 materials reaches the broadest possible audience, including the vast and under-appreciated

375 Internet trade in ornamental species (Secretariat of the Convention on Biological Diversity

376 2010). However, these efforts should be coupled with more directed educational campaigns that

377 target pet enthusiasts that belong to the hundreds of aquarium societies across the United States

378 (e.g., Greater Seattle Aquarium Society), national and international aquarium associations (e.g.,

379 Heart of America Aquarium Society, Canadian Association of Aquarium Clubs, Federation of

380 British Aquatic Societies), and online aquarium forums and websites in which thousands of

381 people exchange information daily. Finally, similar to how boat inspection and cleaning 
382 campaigns target focal "hub" lakes that receive greater amounts of boat traffic (Rothlisberger et

383 al. 2010), we suggest that particular pet stores that sell large numbers of cosmopolitan taxa

384 should be approached (perhaps with financial incentives) to participate in the distribution of 385 educational materials.

386 Our second recommendation is that the responsibility of identifying and regulating

387 species that are at great risk to invade native habitats should be shifted to the aquarium industry.

388 This approach can take a number of routes. Padilla and Williams (2004) recommended that

389 businesses post bonds equal to the cost of repairing damage resulting from the invasion and

390 establishment of aquarium species. We fear that this policy may be costly and difficult to

391 establish, particularly without the strong support of the aquarium industry (including importers,

392 manufacturers, wholesalers, retailers), and conflicts with the "precautionary principle," which

393 would prohibit the entry of any species that could become invasive (McDowall 2004). Peters and

394 Lodge (2009) suggested that the industry be held responsible for demonstrating that a species

395 will not cause "economic or ecological harm" via the creation of lists of allowed and banned

396 species. However, the approach of creating lists of permitted species is not always successful. In

397 Australia, $>40 \%$ of established invasive aquarium species are on a list of species that are

398 permitted for importation (McNee 2002). Additionally, blacklists of banned species can be

399 difficult to enforce, particularly given the lack of knowledge about the ecological effects of most

400 aquarium trade species (Lintermans 2004, Padilla and Williams 2004). The lack of information

401 about most aquarium fish is a more general problem and should be considered a research

402 priority. For example, lethal temperatures for most of the fish species in the aquarium trade are

403 unknown, despite the importance of temperature to invasion success. 
A third possible strategy would involve the aquarium industry, but would shift the

405 responsibility of disposing of unwanted fish to the aquarists; we call this the 'cash for critters'

406 approach. The strategy involves providing a financial incentive to aquarists for returning

407 unwanted live organisms to a pet store, which then can be re-sold (although concern regarding

408 disease transmission may limit this option) or euthanized in a humane manner. The store benefits

409 from re-selling the organism, and from the likelihood that the aquarist will buy more fish,

410 whereas the aquarist could benefit by receiving a store voucher or discount. Notably, over a

411 quarter of aquarists in our survey indicated that they had taken organisms to a store that has a

412 return program.

413 Our final recommendation is to improve legislation on the importation and distribution of

414 nonnative species in the ornamental trade, as well as response guidelines for local, state and

415 federal jurisdictions. The aquarium trade pathway has been noted as having particularly weak

416 regulatory oversight compared to other invasion pathways for fish (Thomas et al. 2009).

417 Legislation that allows for a rapid management response to the detection of nonnative species

418 can be a significant deterrent to their successful establishment: the marine alga, Caulerpa

419 taxifolia, is a prominent aquarium species that invaded and was subsequently contained in

420 California coastal waters by the enactment of a rapid response legislation (Anderson 2005).

421 However, this type of legislation is rare in North America, especially in jurisdictions that have

422 shared international waters, such as the Pacific Northwest (Thomas et al. 2009). The challenge of

423 having different regulations across jurisdictions, i.e., "multiple weak links," has been identified

424 as a significant barrier to preventing the establishment and spread of nonnative species (Peters

425 and Lodge 2009, Thomas et al. 2009). Greater legislative and regulatory control of nonnative

426 aquatic species currently in the ornamental pet trade is needed, but requires coordinated action 
427 across state, provincial, federal, and international jurisdictions. International trade regulations on

428 economically-valuable species can be successfully implemented (e.g., CITES: Ginsberg 2002).

429 Although the US Fish and Wildlife Service's Lacey Act has successfully regulated the trade and

430 prevented secondary spread of a handful of species (e.g., Java sparrow, brown tree snake), the

431 Act is generally considered inefficient at preventing species invasions (Fowler et al. 2007). New

432 federal policy is needed to support the necessary legal tools to better prevent further introduction

433 of potentially and already harmful nonnative animals. One possibility to meet this objective is

434 the recently introduced Nonnative Wildlife Invasion Prevention Act (H.R. 669); a bill that

435 requires the Secretary of the Interior to promulgate regulations establishing a process for

436 assessing the risk of all nonnative wildlife species proposed for importation into the United

437 States, other than those included in a list of approved species issued under this Act. Thus far, Bill

438 H.R. 669 has garnered a mixed reaction: the bill is supported by the National Wildlife Federation

439 and Humane Society of the United States (among other organizations), but is adamantly opposed

440 by the Pet Industry Joint Advisory Commission and a number of other sectors of the aquarium

441 industry including importers and manufacturers.

442 In conclusion, the aquarium and ornamental trade represent a significant invasion

443 pathway for fish and aquatic plants in the Pacific Northwest. Although the introduction pathways

444 associated with ballast water and transport by trailered boats continue to receive the greatest

445 attention with respect to research, management and policy, we cite the need for a greater

446 appreciation of the ornamental pet trade as a source of nonnative species introductions. The

447 greatest risk of nonnative fish species introductions via the aquarium trade likely lies in regions

448 of higher human population sizes, and by association, higher numbers of aquarists and aquarium

449 stores. These regions should be targeted for educational and legislative efforts. However, given 
450 the widespread availability of invasive species through mail-order and e-commerce, even rural

451 areas are susceptible to species invasions via the aquarium trade (Kay and Hoyle 2001). Thus,

452 there is a need for a comprehensive plan of action. Greater attention to educational programs

453 involving the aquarium industry and new legislative action may help to reduce the importance of

454 the aquarium trade as a pathway of freshwater species invasions in the Pacific Northwest.

\section{ACKNOWLEDGEMENTS}

457 We would like to thank local pet stores for access to their invoices, and the questionnaire 458 respondents. Tim Essington, Brian Leung, Kristin Jaeger, Eric Larson, David Lawrence, Thomas

459 Pool, Mariana Tamayo, and two anonymous reviewers provided constructive feedback. Funding 460 support for ALS and JDO was provided by the U.S. Geological Survey Gap Analysis Program.

\section{REFERENCES}

463 Anderson, L. W. J. 2005. California's reaction to Caulerpa taxifolia: a model for invasive species 464 rapid response. Biological Invasions 7: 1003-1016.

465 Bolker, B. M. 2008. Ecological models and data in R. Princeton University Press, Princeton, $466 \quad$ New Jersey.

467 Brett, J. R. 1956. Some principles in the thermal requirements of fishes. Quarterly Review of $468 \quad$ Biology 31: 75-87.

469 Carlton, J. T. and J. B. Geller. 1993. Ecological roulette: the global transport of nonindigenous 470 marine organisms. Science 261: 78-82.

471 Chang, A. L., J. D. Grossman, T. S. Spezio, H. W. Weiskel, J. C. Blum, J. W. Burt, A. A. Muir, 472 J. Piovia-Scott, K. E. Veblen and E. D. Grosholz. 2009. Tackling aquatic invasions: risks 473 and opportunities for the aquarium fish industry. Biological Invasions 11: 773-785. 
474 Chapman, F. A., S. A. Fitz-Coy, E. M. Thunberg and C. M. Adams. 1997. United States of 475 America trade in ornamental fish. Journal of the World Aquaculture Society 28: 1-10.

476 Cheverie, J. C. and W. G. Lynn. 1963. High temperature tolerance and thyroid activity in teleost

477 fish, Tanichthys albonubes. Biological Bulletin 124: 153-162.

478 Cohen, J., N. Mirotchnick and B. Leung. 2007. Thousands introduced annually: the aquarium 479 pathway for non-indigenous plants to the St Lawrence Seaway. Frontiers in Ecology and $480 \quad$ the Environment 5: 528-532.

481 Copp, G. H., L. Vilizzi and R. E. Gozlan. 2010. The demography of introduction pathways, 482 propagule pressure and occurrences of nonnative freshwater fish in England. Aquatic 483 Conservation-Marine and Freshwater Ecosystems 20: 595-601.

484 De Silva, S. S., T. T. T. Nguyen, G. M. Turchini, U. S. Amarasinghe and N. W. Abery. 2009. 485 Alien species in aquaculture and biodiversity: a paradox in food production. Ambio 38: 2448628.

487 DiStefano, R. J., M. E. Litvan and P. T. Horner. 2009. The bait industry as a potential vector for 488 alien crayfish introductions: problem recognition by fisheries agencies and a Missouri $489 \quad$ evaluation. Fisheries 34: 586-597.

490 Dove, A. D. M. and I. Ernst. 1998. Concurrent invaders - four exotic species of Monogenea now 491 established on exotic freshwater fishes in Australia. International Journal for Parasitology $492 \quad 28: 1755-1764$.

493 Duggan, I. C. 2010. The freshwater aquarium trade as a vector for incidental invertebrate fauna. $494 \quad$ Biological Invasions 12: 3757-3770. 
Duggan, I. C., C. A. M. Rixon and H. J. MacIsaac. 2006. Popularity and propagule pressure: determinants of introduction and establishment of aquarium fish. Biological Invasions 8: 377-382.

Ford, T. and T. L. Beitinger. 2005. Temperature tolerance in the goldfish, Carassius auratus. Journal of Thermal Biology 30: 147-152.

Fowler, A. J., D. M. Lodge and J. F. Hsia. 2007. Failure of the Lacey Act to protect U.S. ecosystems against animal invasions. Frontiers in Ecology and the Environment 5: 353359.

Froese, R. and D. Pauly. 2009. FishBase. www.fishbase.org, version (05/2009).

Gertzen, E., O. Familiar and B. Leung. 2008. Quantifying invasion pathways: fish introductions from the aquarium trade. Canadian Journal of Fisheries and Aquatic Sciences 65: 12651273.

Ginsberg, J. 2002. CITES at 30, or 40. Conservation Biology 16: 1184-1191.

Hernández, R. M. and R. L. F. Bückle. 2002. Temperature tolerance polygon of Poecilia sphenops Valenciennes (Pisces : Poeciliidae). Journal of Thermal Biology 27: 1-5.

Kay, S. H. and S. T. Hoyle. 2001. Mail order, the internet, and invasive aquatic weeds. Journal of Aquatic Plant Management 39: 88-91.

Keller, R. P. and P. S. Lake. 2007. Potential impacts of a recent and rapidly spreading coloniser of Australian freshwaters: oriental weatherloach (Misgurnus anguillicaudatus). Ecology of Freshwater Fish 16: 124-132.

Keller, R. P. and D. M. Lodge. 2007. Species invasions from commerce in live aquatic organisms: problems and possible solutions. BioScience 57: 428-436.

Legendre, P. and L. Legendre. 1998. Numerical ecology. Elsevier, Amsterdam, The Netherlands. 
518 Leung, B., J. M. Bossenbroek and D. M. Lodge. 2006. Boats, pathways, and aquatic biological

519 invasions: estimating dispersal potential with gravity models. Biological Invasions 8: 241$520 \quad 254$.

521 Lintermans, M. 2004. Human-assisted dispersal of alien freshwater fish in Australia. New 522 Zealand Journal of Marine and Freshwater Research 38: 481-501.

523 Lintermans, M., T. Rutzou and K. Kukolic. 1990. The status, distribution and possible impacts of 524 the oriental weatherloach Misgurnus anguillicaudatus in the Ginninderra Creek catchment. 525 Australian Capital Territory Parks and Conservation Service, Research Report 2, 526 Tuggeranong, Australia.

527 Litvak, M. K. and N. Mandrak. 1993. Ecology of freshwater baitfish use in Canada and the $528 \quad$ United States. Fisheries 18: 6-13.

529 Lodge, D. M., S. Williams, H. J. MacIsaac, K. R. Hayes, B. Leung, S. Reichard, R. N. Mack, P. 530 B. Moyle, M. Smith, D. A. Andow, J. T. Carlton and A. McMichael. 2006. Biological 531 invasions: recommendations for U.S. policy and management. Ecological Applications 16: $532 \quad 2035-2054$.

533 Logan, D. J., E. L. Bibles and D. F. Markle. 1996. Recent collections of exotic aquarium fishes 534 in the freshwaters of Oregon and thermal tolerance of oriental weatherfish and pirapatinga. $535 \quad$ California Fish and Game 82: 66-80.

536 McDowall, R. M. 2004. Shoot first, and then ask questions: a look at aquarium imports and 537 invasiveness in New Zealand. New Zealand Journal of Marine and Freshwater Research $538 \quad 38: 503-510$. 
McNee, A. 2002. A national approach to the management of exotic species in the aquarium trade: an inventory of exotic freshwater fish species. Bureau of Rural Sciences, Canberra, Australia.

Mote, P. W. and E. P. Salathé Jr. 2010. Future climate in the Pacific Northwest. Climatic Change 102: 29-50.

Moyle, P. B. and M. P. Marchetti. 2006. Predicting invasion success: freshwater fishes in California as a model. BioScience 56: 515-524.

Naylor, R. L., S. L. Williams and D. R. Strong. 2001. Aquaculture: a gateway for exotic species. Science 294: 1655-1656.

Opuszyňski, K., A. Lirski, L. Myszkowski and J. Wolnicki. 1989. Upper lethal and rearing temperatures for juvenile common carp, Cyprinus carpio L., and silver carp, Hypophthalmichthys molitrix (Valenciennes). Aquaculture Research 20: 287-294.

Padilla, D. K. and S. L. Williams. 2004. Beyond ballast water: aquarium and ornamental trades as sources of invasive species in aquatic ecosystems. Frontiers in Ecology and the Environment 2: 131-138.

Peters, J. A. and D. M. Lodge. 2009. Invasive species policy at the regional level: a multiple weak links problem. Fisheries 34: 373-381.

R Development Core Team. 2010. R: a language and environment for statistical computing. R Foundation for Statistical Computing.

Rahel, F. J. and J. D. Olden. 2008. Assessing the effects of climate change on aquatic invasive species. Conservation Biology 22: 521-533.

Ricciardi, A. 2006. Patterns of invasion in the Laurentian Great Lakes in relation to changes in vector activity. Diversity and Distributions 12: 425-433. 
562 Ricciardi, A. and J. B. Rasmussen. 1998. Predicting the identity and impact of future biological 563 invaders: a priority for aquatic resource management. Canadian Journal of Fisheries and $564 \quad$ Aquatic Sciences 55: 1759-1765.

565 Rixon, C. A. M., I. C. Duggan, N. M. N. Bergeron, A. Ricciardi and H. J. MacIsaac. 2005.

566 Invasion risks posed by the aquarium trade and live fish markets on the Laurentian Great

$567 \quad$ Lakes. Biodiversity and Conservation 14: 1365-1381.

568 Rothlisberger, J. D., W. L. Chadderton, J. McNulty and D. M. Lodge. 2010. Aquatic invasive 569 species transport via trailered boats: what is being moved, who is moving it, and what can $570 \quad$ be done. Fisheries 35: 121-132.

571 Ruiz, G. M. and J. T. Carlton. 2003. Invasion vectors: a conceptual framework for management.

572 In G. M. Ruiz and J. T. Carlton [eds.]. Invasive species: vectors and management 573 strategies. Island Press, Washington, DC.

574 Ruiz, G. M., J. T. Carlton, E. D. Grosholz and A. H. Hines. 1997. Global invasions of marine 575 and estuarine habitats by non-indigenous species: mechanisms, extent, and consequences. $576 \quad$ American Zoologist 37: 621-632.

577 Sanderson, B. L., K. A. Barnas and A. M. W. Rub. 2009. Nonindigenous species of the Pacific 578 Northwest: an overlooked risk to endangered salmon? BioScience 59: 245-256.

579 Schlaepfer, M. A., C. Hoover and C. K. Dodd. 2005. Challenges in evaluating the impact of the 580

581 Secretariat of the Convention on Biological Diversity. 2010. Pets, aquarium, and terrarium 582 species: best practices for addressing risks to biodiversity. Secretariat of the Convention on 583 Biological Diversity, Montreal, Canada. 
584 Smith, K. F., M. D. Behrens, L. M. Max and P. Daszak. 2008. U.S. drowning in unidentified

585 fishes: scope, implications, and regulation of live fish import. Conservation Letters 1: 103$586 \quad 109$.

587 State of Washington Joint Legislative Audit \& Review Committee. 2010. Activities supporting recreational boating in Washington. Olympia, WA.

589 Tabor, R. A., E. Warner and S. Hager. 2001. An oriental weatherfish (Misgurnus anguillicaudatus) population established in Washington State. Northwest Science 75: 7276.

592 Thomas, V. G., C. Vasarhelyi and A. J. Niimi. 2009. Legislation and the capacity for rapidresponse management of nonindigenous species of fish in contiguous waters of Canada and the USA. Aquatic Conservation-Marine and Freshwater Ecosystems 19: 354-364.

595 Vander Zanden, M. J. and J. D. Olden. 2008. A management framework for preventing the secondary spread of aquatic invasive species. Canadian Journal of Fisheries and Aquatic Sciences 65: 1512-1522.

598 Wolf, K. 1988. Fish viruses and fish viral diseases. Comstock Publishing Associates, Ithaca, NY. 599 
602 Table 1. Frequency of occurrence of aquarium fish species in pet stores $(>75 \%)$ and minimum

603 optimum temperature $\left({ }^{\circ} \mathrm{C}\right)$.

\begin{tabular}{|c|c|c|c|}
\hline Scientific name & Common name & $\begin{array}{c}\text { Frequency of } \\
\text { occurrence } \\
(\%)\end{array}$ & $\begin{array}{c}\text { Minimum } \\
\text { optimum } \\
\text { temperature } \\
\left({ }^{\circ} \mathrm{C}\right) \\
\end{array}$ \\
\hline Puntius tetrazona ${ }^{\mathrm{a}}$ & tiger barb & 100.0 & 20.0 \\
\hline Trichogaster trichopterus ${ }^{\mathrm{a}}$ & three spot gourami & 100.0 & 22.0 \\
\hline Betta splendens ${ }^{\mathrm{a}}$ & Siamese fighting fish & 96.7 & 24.0 \\
\hline Carassius auratus $^{\mathrm{a}, \mathrm{b}}$ & goldfish & 96.7 & 0.0 \\
\hline Danio rerio $^{\mathrm{c}}$ & zebra danio & 96.7 & 18.0 \\
\hline Gymnocorymbus ternetzi $i^{\mathrm{a}}$ & black tetra & 96.7 & 20.0 \\
\hline Hemigrammus erythrozonus $^{\mathrm{c}}$ & glowlight tetra & 96.7 & 24.0 \\
\hline Paracheirodon innesi $^{\mathrm{a}}$ & neon tetra & 96.7 & 20.0 \\
\hline Poecilia latipinna $^{\mathrm{a}}$ & sailfin molly & 96.7 & 20.0 \\
\hline Poecilia reticulata ${ }^{\mathrm{a}}$ & guppy & 96.7 & 18.0 \\
\hline Poecilia sphenops $^{\mathrm{a}}$ & molly & 96.7 & 18.0 \\
\hline Puntius titteya ${ }^{\mathrm{c}}$ & cherry barb & 96.7 & 23.0 \\
\hline Xiphophorus maculatus ${ }^{\mathrm{a}}$ & southern platyfish & 96.7 & 18.0 \\
\hline Colisa lalia ${ }^{\mathrm{a}}$ & dwarf gourami & 90.0 & 25.0 \\
\hline Pristella maxillaris & $\mathrm{x}$-ray tetra & 90.0 & 24.0 \\
\hline Puntius conchonius $^{\mathrm{a}}$ & rosy barb & 90.0 & 18.0 \\
\hline Astronotus ocellatus $^{\mathrm{a}}$ & oscar & 83.3 & 22.0 \\
\hline Epalzeorhynchos frenatum & rainbow sharkminnow & 83.3 & 24.0 \\
\hline Gyrinocheilus aymonieri $^{\mathrm{a}}$ & Chinese algae-eater & 83.3 & 25.0 \\
\hline Moenkhausia sanctaefilomenae & redeye tetra & 83.3 & 22.0 \\
\hline Trigonostigma heteromorpha & harlequin rasbora & 83.3 & 22.0 \\
\hline Balantiocheilos melanopterus ${ }^{\mathrm{a}}$ & tricolor sharkminnow & 80.0 & 22.0 \\
\hline Corydoras paleatus $^{\mathrm{a}}$ & peppered corydoras & 80.0 & 18.0 \\
\hline Devario aequipinnatus & giant danio & 80.0 & 22.0 \\
\hline Xiphophorus helleri $^{\mathrm{a}}$ & green swordtail & 80.0 & 22.0 \\
\hline Hyphessobrycon eques ${ }^{\mathrm{c}}$ & jewel tetra & 76.7 & 22.0 \\
\hline Labidochromis caeruleus & blue streak hap & 76.7 & 23.0 \\
\hline Metynnis hypsauchen ${ }^{\mathrm{a}}$ & silver dollar & 76.7 & 24.0 \\
\hline Tanichthys albonubes $^{\mathrm{a}}$ & white cloud mountain minnow & 76.7 & 18.0 \\
\hline
\end{tabular}


607 Table 2. Frequency of occurrence of aquarium plant species in pet stores $(>25 \%)$.

608

\begin{tabular}{llc}
\hline Scientific name & Common name & $\begin{array}{c}\text { Frequency of } \\
\text { occurrence (\%) }\end{array}$ \\
\hline Echinodorus amazonicus & Amazon sword & 76.7 \\
Microsorium pteropus & java fern & 73.3 \\
Hygrophila difformis & wisteria & 70.0 \\
Cryptocoryne wendtii $^{\text {a }}$ & Cryptocoryne wendtii & 63.3 \\
Ceratophyllum demersum & hornwort & 56.7 \\
Echinodorus tennellus & narrow leaf chain sword & 56.7 \\
Acorus gramineus & Japanese rush & 50.0 \\
Dracena sanderiana & green sandriana & 50.0 \\
Nymphoides aquatica & banana & 50.0 \\
Ophiopogon japonicus & mondo grass & 50.0 \\
Trichomanes javanicum & Trichomanes javanicum & 46.7 \\
Echinodorus paniculatus & bleheri sword & 43.3 \\
Echinodorus argentinensis & Argentine sword & 40.0 \\
Anubias barteri & Anubias barteri & 36.7 \\
Vesicularia dubyana & java moss & 36.7 \\
Crinum thaianum & crinum bulb & 33.3 \\
Echinodorus osiris & melon sword & 33.3 \\
Bacopa monnieri & moneywort & 26.7 \\
Sagittaria subulatab & dwarf sagittaria & 26.7 \\
Spathiphyllum wallisii & peace lily & 26.7 \\
\hline a listed as USGS Nonindigenous Species & \\
species within same genus listed as Washington State Noxious Aquatic Weed &
\end{tabular}

611 
612 Table 3. Comparison of the aquarium trade and trailered boats as pathways of nonnative species

613 invasions. This illustrative comparison indicates that the threat posed by the aquarium trade may

614 be comparable to that of boat trailers. For establishment success, categories of low, moderate,

615 and high are simply qualitative characterizations based on relative comparisons of potential

616 establishment between taxonomic groups.

\begin{tabular}{|c|c|c|}
\hline Characteristic & Aquarium trade & Trailered boats \\
\hline Taxonomy & $\begin{array}{l}\text { fish, aquatic invertebrates, and } \\
\text { plants } 1,2,3\end{array}$ & aquatic invertebrates and plants ${ }^{4}$ \\
\hline Propagule pressure & 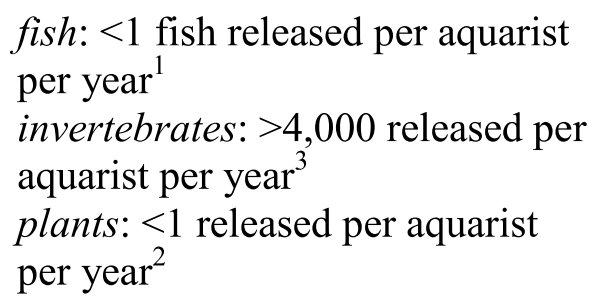 & $\begin{array}{l}\text { invertebrates }+ \text { plants: } \sim 37 \\
\text { organisms per boat }{ }^{4}\end{array}$ \\
\hline Vector strength & $\begin{array}{l}\text { estimated number of households } \\
\text { in Washington State with an } \\
\text { aquarium }=227,140^{5}\end{array}$ & $\begin{array}{l}\text { estimated number of recreational } \\
\text { boats in Washington State }= \\
264,000^{6}\end{array}$ \\
\hline Establishment success & $\begin{array}{l}\text { fish: low, Allee effects } \\
\text { invertebrates: moderate, some } \\
\text { asexual reproduction } \\
\text { plants: high, vegetative } \\
\text { reproduction }\end{array}$ & $\begin{array}{l}\text { invertebrates: moderate, some } \\
\text { asexual reproduction } \\
\text { plants: high, vegetative } \\
\text { reproduction }\end{array}$ \\
\hline $\begin{array}{l}\text { Prevention } \\
\text { compliance }\end{array}$ & $\begin{array}{l}5.0-6.4 \% \text { of aquarists release live } \\
\text { fish }^{1,7}\end{array}$ & $\begin{array}{l}13 \% \text { of boaters never remove } \\
\text { aquatic plants }{ }^{4}\end{array}$ \\
\hline $\begin{array}{l}\text { Management and } \\
\text { educational challenges }\end{array}$ & $\begin{array}{l}\text { spatially-diffuse: target } \\
\text { pet/aquarium stores and groups }\end{array}$ & $\begin{array}{l}\text { spatially-specific: target high } \\
\text { traffic boat launches }\end{array}$ \\
\hline
\end{tabular}

this study

$618{ }^{2}$ Cohen et al. (2007)

$619{ }^{3}$ Duggan (2010)

$620{ }^{4}$ Rothlisberger et al. (2010)

62152000 US Census: http://www.census.gov/main/www/cen2000.html and based on the percentage

622 of U.S. households that own fishes (10.6\%) according to values from Chapman et al. (1997).

$623{ }^{6}$ State of Washington Joint Legislative Audit and Review Committee (2010). Recreational

624 vessels include sailboats, yachts, and motorized boats that were registered in 2008; only a

625 fraction of these boats are trailered.

$626{ }^{7}$ Gertzen et al. (2008)

627

628 
629 Table 4. List of educational resources on the release of aquarium organisms.

\begin{tabular}{|c|c|}
\hline Source & Website \\
\hline California Sea Grant & http://www-csgc.ucsd.edu/extension/ \\
\hline Convention on Biological Diversity & http://www.cbd.int/invasive/ \\
\hline $\begin{array}{l}\text { Don't Release a Pest! University of } \\
\text { Southern California - Sea Grant }\end{array}$ & http://www.usc.edu/org/seagrant/caulerpa/index.html \\
\hline Global Invasive Species Program & http://www.gisp.org/ \\
\hline Habitattitude & http://www.habitattitude.net/ \\
\hline Oregon Sea Grant & $\mathrm{http}: / /$ seagrant.oregonstate.edu/themes/invasives/index.html \\
\hline Ornamental Aquatic Trade Association & http://www.ornamentalfish.org/ \\
\hline Pet Industry Joint Advisory Council & http://www.pijac.org/aquatic/ \\
\hline United States Geological Survey & http://nas.er.usgs.gov/taxgroup/fish/docs/dont_rel.asp \\
\hline
\end{tabular}




\section{Figure CAPTIONS}

633 Figure 1: A) Number of pet stores in Washington state counties (US Economic Census 2007: http://www.census.gov/econ/census07/), B) location of stores included in the regional

Figure 2: Total monthly number of fish (i.e., feeders and ornamentals), ornamental fish, and plant individuals purchased by the store (reflecting monthly sales). Note that plants are represented on the right-hand axis.

Figure 3: Mean annual stream water temperatures $\left({ }^{\circ} \mathrm{C}\right)$ in Washington streams (left panel), thermal preferenda $\left({ }^{\circ} \mathrm{C}\right)$ of certain common fish species found in the aquarium trade (right panel). Water temperatures are represented by a box plot, where the centre line is the median, the lower and upper box boundaries are the $25^{\text {th }}$ and $75^{\text {th }}$ percentiles, the whiskers are the $10^{\text {th }}$ and $90^{\text {th }}$ percentiles, and outliers are represented by circles. The shaded boxes in the background correspond to the $10^{\text {th }}$ and $90^{\text {th }}$ percentiles of stream temperatures (dark grey) and the most extreme outliers (light grey). Thermal preferenda for the fish species are represented by ranges, where the box represents the optimal temperature range and the whiskers represent the upper and lower lethal limits. Fish species are arranged by increasing thermal range. Note that water temperature data was not available for lakes, although we would expect that introductions occur in both lakes and streams.

Figure 4: Comparisons of chain and independent pet stores for A) number of fish individuals per store, B) number of fish species per store, and C) number of plant species per store. Center line in box plots represents median, lower and upper box boundaries are the $25^{\text {th }}$ and $75^{\text {th }}$ percentiles, and whiskers are the $10^{\text {th }}$ and $90^{\text {th }}$ percentiles. Outliers are 
represented by circles. Letters above the bars represent the results of Tukey HSD post hoc tests, where different letters indicate significant differences between store categories $(p<0.05)$

658 Figure 5: Non-metric multidimensional scaling of relative abundance of aquarium fishes in pet stores in the Puget Sound area using Bray-Curtis dissimilarity. Chain stores (triangles, $\mathrm{n}$ $=8$; squares, $\mathrm{n}=14$ ) are contrasted with a set of independent stores (circles, $\mathrm{n}=8$ ). Common names of fishes highly correlated with NMDS axes are indicated on the outer edges of the graph. NMDS stress $=10.2, p=0.02$ on three dimensions. Ellipses drawn around the outer edges of groups of stores are simply for illustration. Star indicates the species score of oriental weatherfish (Misgurnus anguillicaudatus), one of several aquarium fishes with an established population in Washington.

Figure 6: Histogram of estimated relative frequency of number of individual fish released annually in King County. The median value of fish released each year is 2,536 , the mean is 4,707 , and the upper $95^{\text {th }}$ confidence interval (indicated by grey box) is 20,869 . 

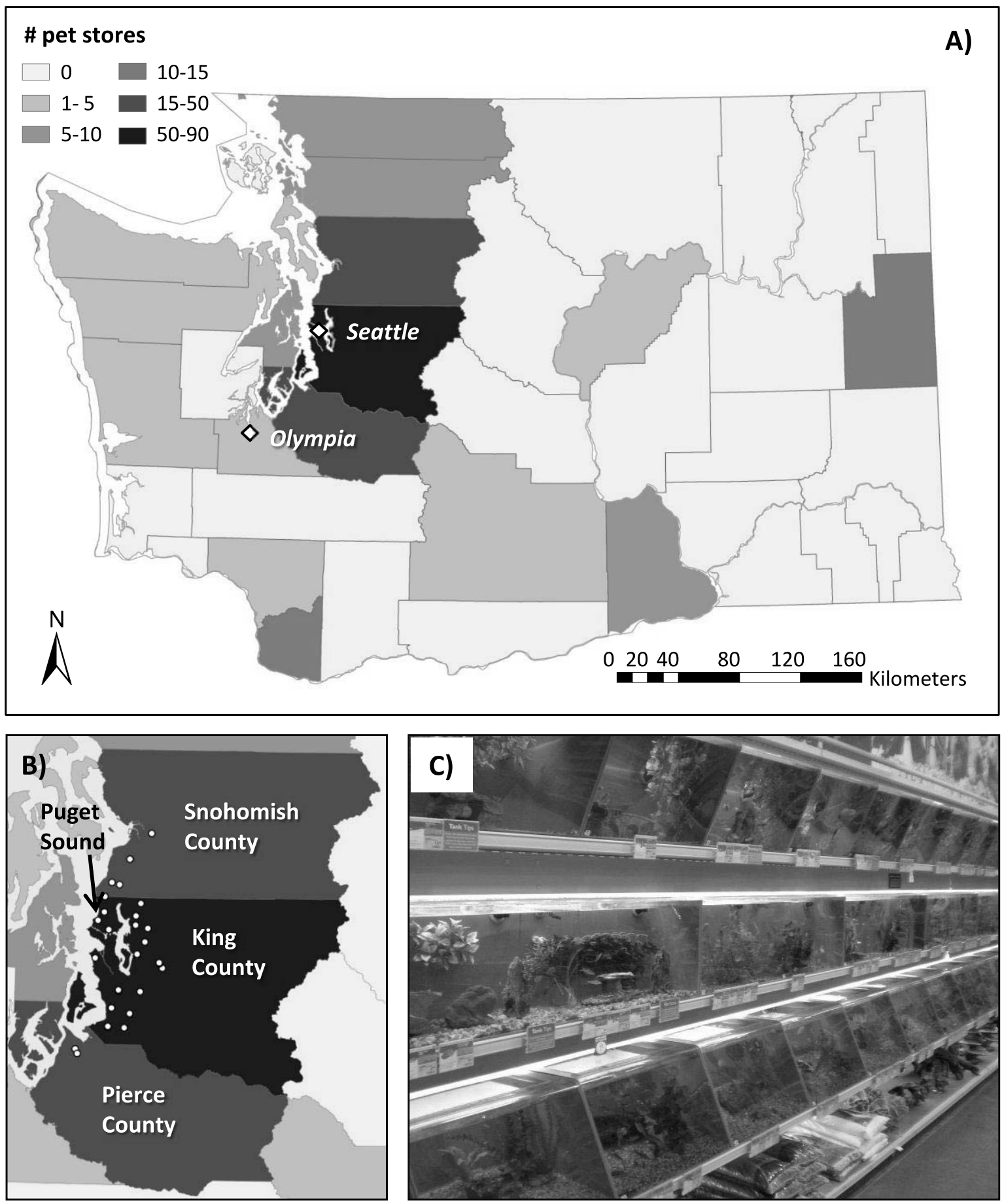

Figure 1 


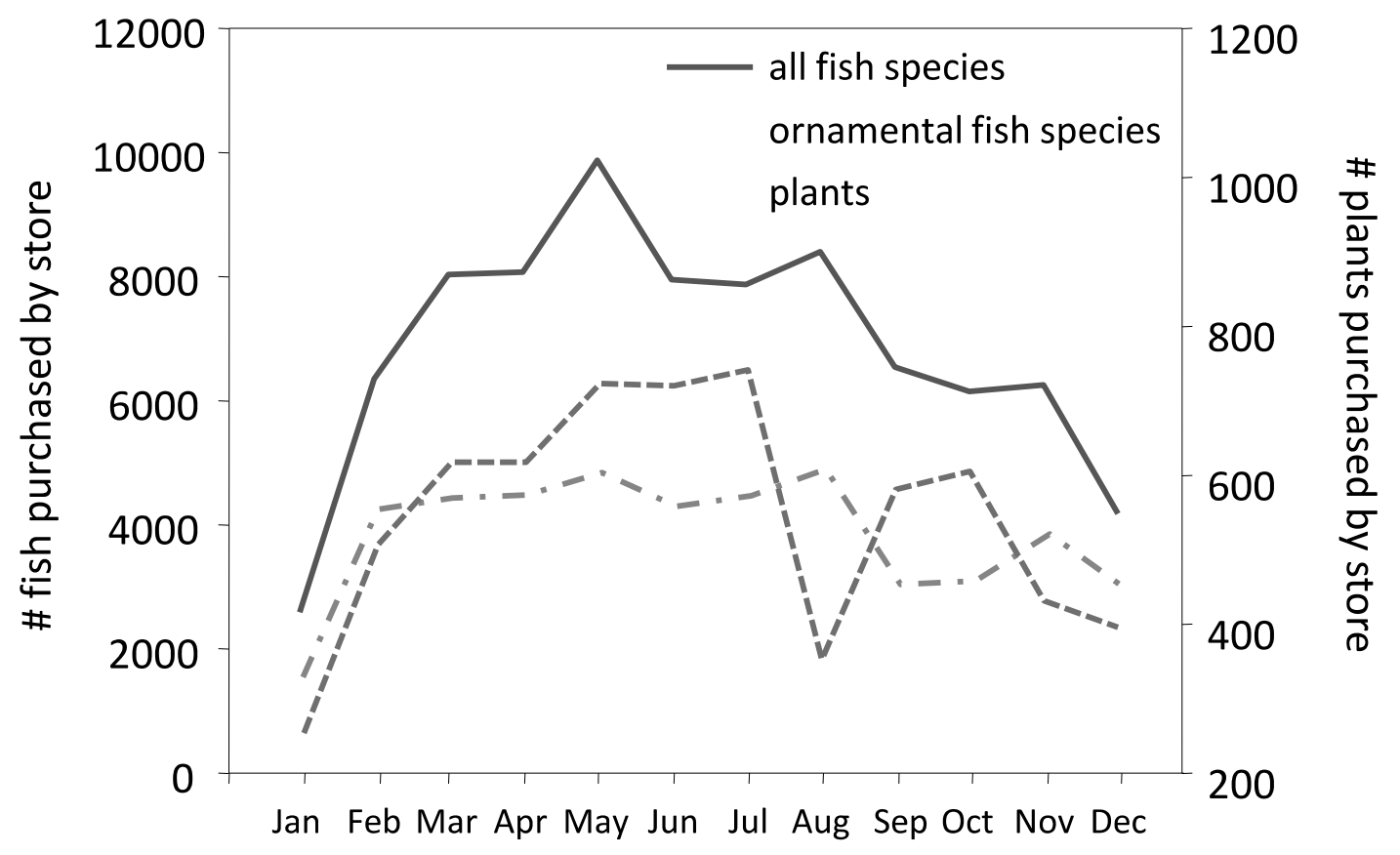

Figure 2 


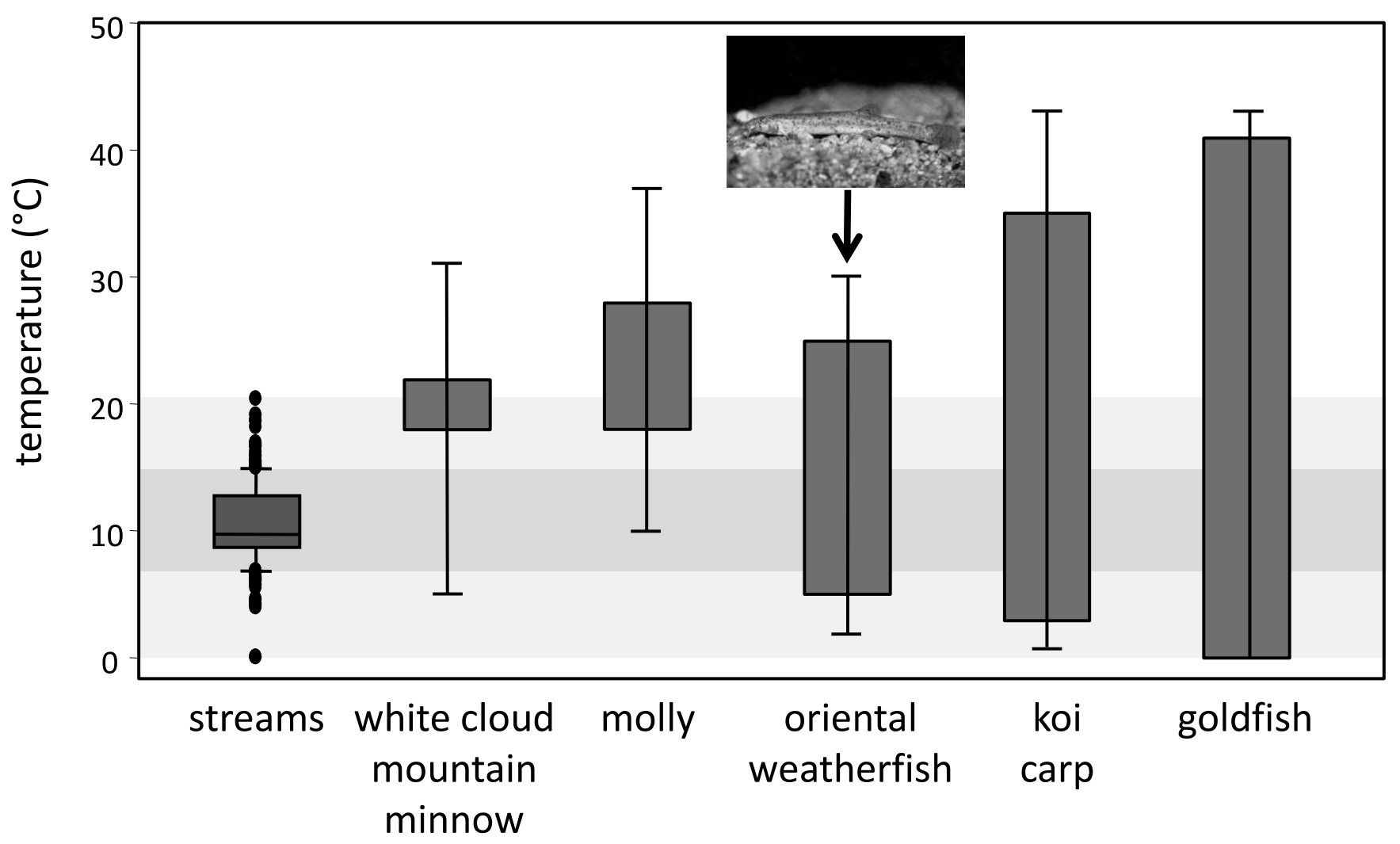

Figure 3 

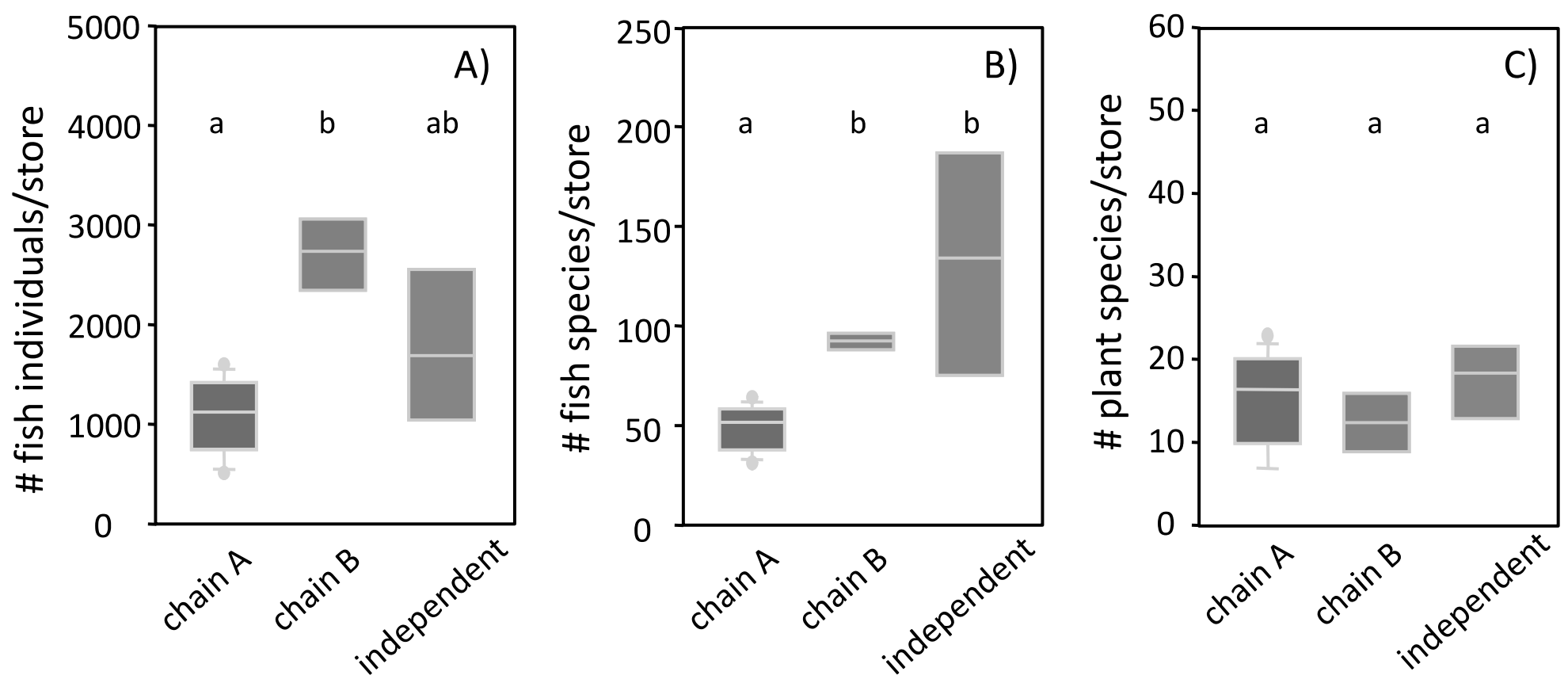

Figure 4 


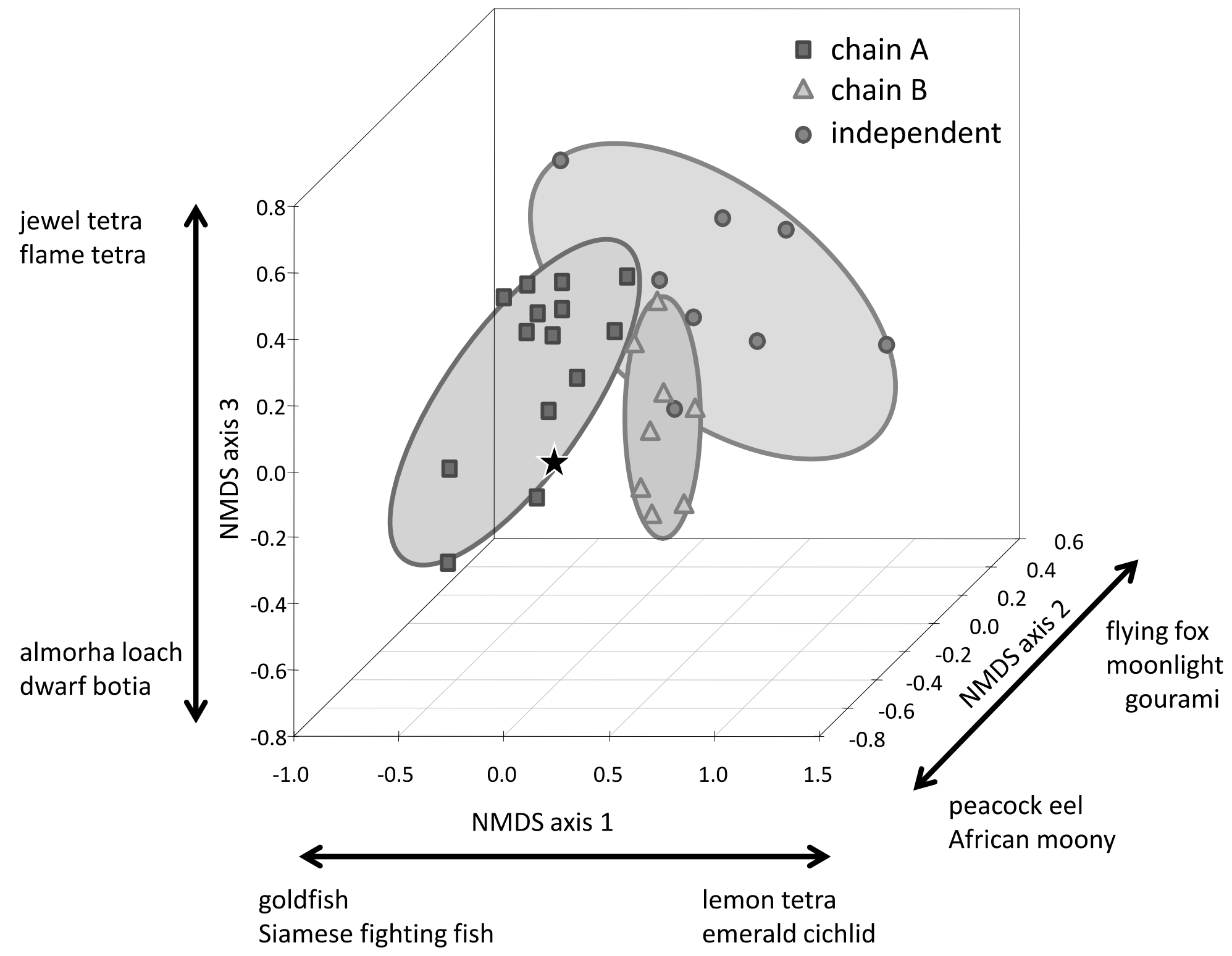

Figure 5 


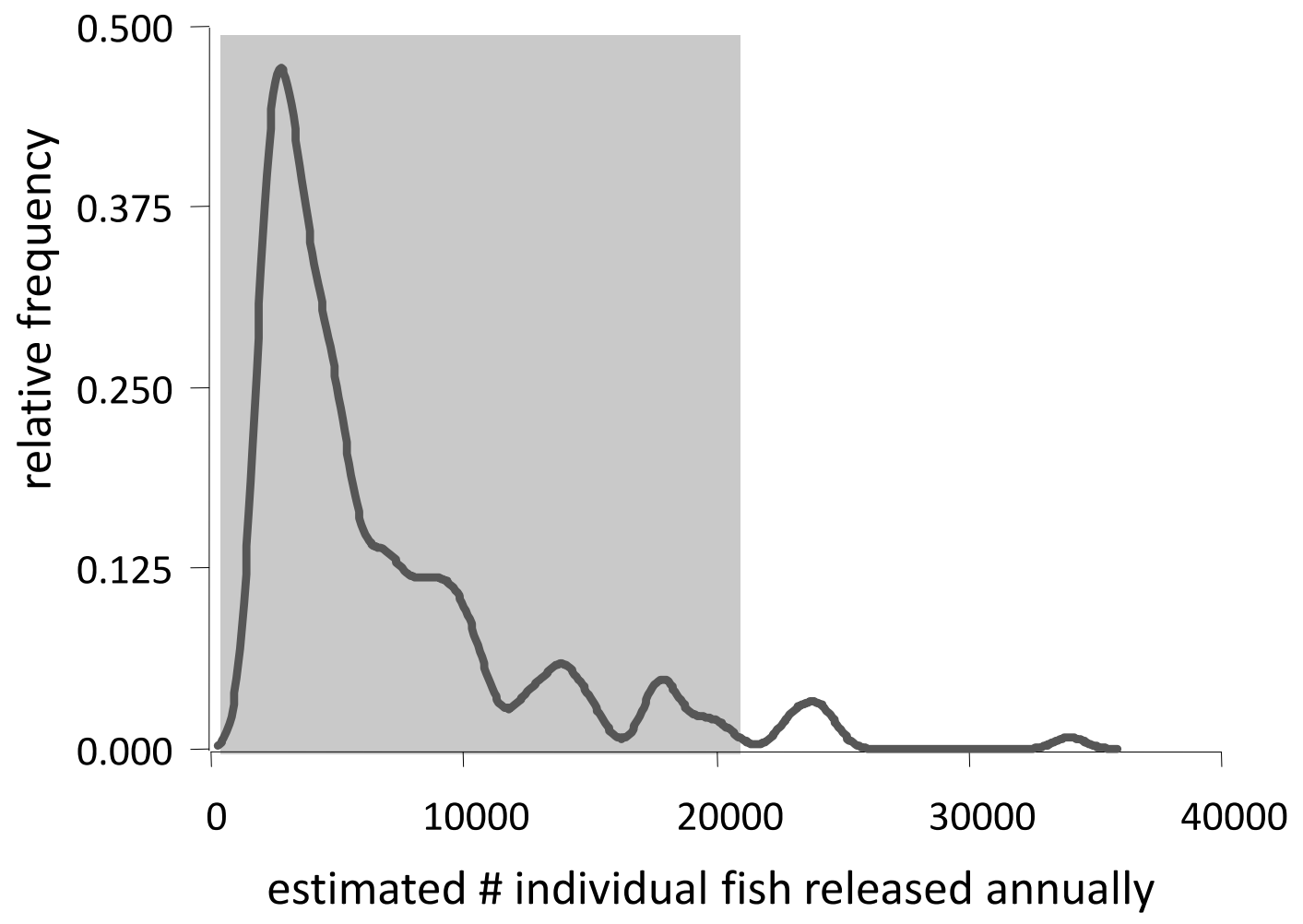

Figure 6 